Article

\title{
An Electrochemical Approach for the Selective Detection of Cancer Metabolic Creatine Biomarker with Porous Nano-Formulated CMNO Materials Decorated Glassy Carbon Electrode
}

\author{
Mohammed M. Rahman ${ }^{1} *$ (D) Md. M. Alam ${ }^{2}$, Abdullah M. Asiri ${ }^{1}$ and Firoz. A. D. M. Opo ${ }^{3,4}$ \\ 1 Center of Excellence for Advanced Materials Research (CEAMR), King Abdulaziz University, \\ P.O. Box 80203, Jeddah 21589, Saudi Arabia; amasiri@kau.edu.sa \\ 2 Department of Chemical Engineering and Polymer Science, Shahjalal University of Science and Technology, \\ Sylhet 3100, Bangladesh; mmalamsust@gmail.com \\ 3 Department of Biomedical Science, College of Natural Sciences, Chosun University, Chosun 61452, Korea; \\ fadmopo@gmail.com \\ 4 Phytochemistry Research Laboratory, Department of Pharmacy, University of Asia Pacific, \\ Dhaka 1000, Bangladesh \\ * Correspondence: mmrahman@kau.edu.sa
}

Received: 6 November 2020; Accepted: 7 December 2020; Published: 10 December 2020

\begin{abstract}
The facile wet-chemical technique was used to prepare the low-dimensional nano-formulated porous mixed metal oxide nanomaterials $\left(\mathrm{CuO} \cdot \mathrm{Mn}_{2} \mathrm{O}_{3} . \mathrm{NiO} ; \mathrm{CMNO} \mathrm{NMs}\right)$ in an alkaline medium at low temperature. Detailed structural, morphological, crystalline, and functional characterization of CMNO NMs were performed by X-ray photoelectron spectroscopy (XPS), powder X-ray diffraction (XRD), ultraviolet-visible spectroscopy (UV-vis), Fourier-transform infrared spectroscopy (FTIR), field emission scanning electron microscopy (FESEM), and energy-dispersive X-ray spectroscopy (EDS) analyses. An efficient and selective creatine (CA) sensor probe was fabricated by using CMNO NMs decorated onto glassy carbon electrode (GCE) as CMNO NMs/GCE by using Nafion adhesive ( $5 \%$ suspension in ethanol). The relation of current versus the concentration of CA was plotted to draw a calibration curve of the CMNO NMs/GCE sensor probe, which was found to have a very linear value $\left(\mathrm{r}^{2}=0.9995\right)$ over a large dynamic range (LDR: $\left.0.1 \mathrm{nM} \sim 0.1 \mathrm{mM}\right)$ for selective CA detection. The slope of LDR by considering the active surface area of GCE $\left(0.0316 \mathrm{~cm}^{2}\right)$ was applied to estimate the sensor sensitivity $\left(14.6308 \mu \mathrm{A \mu M}^{-1} \mathrm{~cm}^{-2}\right)$. Moreover, the detection limit $(21.63 \pm 0.05 \mathrm{pM})$ of CMNO MNs modified GCE was calculated from the signal/noise $(\mathrm{S} / \mathrm{N})$ ratio at 3 . As a $\mathrm{CA}$ sensor probe, it exhibited long-term stability, good reproducibility, and fast response time in the detection of CA by electrochemical approach. Therefore, this research technique is introduced as a promising platform to develop an efficient sensor probe for cancer metabolic biomarker by using nano-formulated mixed metal oxides for biochemical as well as biomedical research for the safety of health care fields.
\end{abstract}

Keywords: porous nano-formulated CMNO nanomaterials; creatine sensor; wet-chemical technique; glassy carbon electrode; clinical research; health care field

\section{Introduction}

Biologically, the CA is synthesized in the kidney and liver into the human body, which is later distributed through the blood circulation system. Then it is carried to the high energy demanded tissues such as the brain and skeletal muscle [1,2] in the human body. It is also available in foods such as meat and fish [3], which are commonly used in human food chains. Besides this, CA can also be 
synthesized in the laboratory if needed. The most important thing is that the CA performs a vital role to produce energy and control of $\mathrm{pH}$ of the buffer system into the living tissues. Therefore, a continuous supply of CA is necessary either through food or biosynthesis in the human body [4]. On the other hand, the deficiency of CA may cause several neurological syndromes in the human body such as autism, extrapyramidal syndrome, hypotonia, auto-mutilating behavior, delays in speech acquisition and mental retardation [5-7]. On considering the physiological effects of CA, it is very important to the development of a reliable and effective quantification method of CA in biological samples. Some existing conventional methods are generally used for quantification of CA in human fluids, such as colorimetry [8], spectrophotometry [9], and fluorimetry [10]. However, these conventional methods still have some drawbacks such as heavy and expensive instruments, time-consuming, costly reagents and un-portable to in situ biomarker detection. The derivative, CA riboside, is a novel and efficient metabolite of cancer metabolism in the living body. It is known as a urinary diagnostic biomarker of lung and liver cancer risk and prognosis. Besides this, CA riboside is highly positive, which is correlated with tumors and urine derived from human lung and liver cancers [11]. Recently, the electrochemical sensor based on the electrochemical method becoming popular to detect and quantification of ionic, chemical, and bio-chemical spices [12-20]. Besides this, the sensitivity and selectivity of the sensor probe can enhance by using various nanomaterials as well as nanocomposites as the sensing mediator [21-26]. Therefore, the aim of this research is to develop an enzyme-less sensor by applying CMNO materials onto GCE with the help of a conducting coating binder.

Nowadays, interfacial mediators such as nanomaterials, nanocomposites, and hybrid materials are used for the reliable detection of unsafe toxic chemicals as well as biological stuff [27-29]. Generally, $\mathrm{CuO}$ is a p-type semiconductor having an optical band-gap of $1.2 \mathrm{eV}$ and electrical conductivity of $7.8 \times 10^{-4} \mathrm{~W}^{-1} \mathrm{~cm}^{-1}$ [30]. Due to the unique electrical, magnetic and optical properties of $\mathrm{CuO}$, it was found to use as a sensor, catalyst, supercapacitors, infrared filters, and magnetic storage [31]. Therefore, it is also applied to the detection of 3-chlorophenol [31], bicarbonate [32], and bilirubin [33] successively as electrochemical sensors. Recently, $\mathrm{Mn}_{2} \mathrm{O}_{3}$ has been investigated widely as an electrochemical sensor for its physio-electrochemical properties, including direct bang-gap energy $(1.2 \mathrm{eV})$ and conductivity $\left(10^{-6} \sim 10^{3} \mathrm{~W}^{-1} \mathrm{~cm}^{-1}\right)$. These properties are highly considered in the viewpoint of electrochemical sensor applications [34,35]. Moreover, $\mathrm{NiO}$ is another efficient p-type semiconductor with an intrinsic band-gap of 3.7 4.0 eV. It is widely applied as sensors, supercapacitors, electronic devices, photo-catalysts, and catalysts [36,37]. It is found that $\mathrm{CuO}, \mathrm{Mn}_{2} \mathrm{O}_{3}$, and $\mathrm{NiO}$ have strong evidenced to apply as electrochemical sensors for the detection of unsafe chemicals and biochemical for the safety of living things. Therefore, this study is introduced for the development of a selective sensor probe by using the ternary mixtures of $\mathrm{CuO}, \mathrm{Mn}_{2} \mathrm{O}_{3}$, and $\mathrm{NiO}$.

The prospective and promising electrochemical technique for the real-time analysis of biological samples by using CMNO nanomaterials deposited GCE were fabricated and applied to the successive detection of unsafe CA. Calibration of the sensor probe is plotted from the linear portion of current versus concentration of CA. It is used to calculate the sensor analytical parameters such as sensitivity, LDR, and DL of the proposed sensor. To the best of our knowledge, CMNO nanomaterial is used for the first time as an efficient sensor substrate for the selective detection of CA in the phosphate buffer solution. Besides this, the sensitivity, reproducibility, detection limit, response time, convenience with low cost, simplicity, and capability of rapid diagnosis are analyzed with the fabricated CMNO NMs/GCE sensor probe for CA detection. Therefore, this sensor probe fabrication would be an excellent approach for the development of reliable and selective CA detection by using nano-formulated mixed metal oxides or hybrid materials in biomedical and health care fields on a broad scale. 


\section{Experimental}

\subsection{Materials and Methods}

To prepare the nano-formulated CMNO NMs, the precursors $\mathrm{NiSO}_{4} \cdot 6 \mathrm{H}_{2} \mathrm{O}, \mathrm{MnSO}_{4} \cdot \mathrm{H}_{2} \mathrm{O}$, and $\mathrm{CuCl}_{2} \cdot 2 \mathrm{H}_{2} \mathrm{O}$ were purchased from Merck, Germany. For this experiment, $\mathrm{L}(+)$-lactic acid, D-glucose, folic acid, cholesterol, choline, L-glutamic acid, dopamine, L(+)-aspartic acid, ascorbic acid, CA, 5\% Nafion suspension, mono- and disodium phosphate were purchased from Sigma-Aldrich (Sigma-Aldrich Corp., St. Louis, MO, US) company. An XPS (Thermo Scientific with A1 K-a1 radiation sources and a beam spot size of $300.0 \mu \mathrm{m}$, which is performed at $200.0 \mathrm{eV}$, and $10^{-8}$ Torr pressure) was utilized for the CMNO NMs to evaluate the respective quantitative and chemical state information from the surface of nanomaterials. The morphology and elemental compositions of CMNO NMs were simultaneously investigated by using FESEM (JEOL, JSM-7600F, Tokyo, Japan) equipped with EDS. The functional group and photo-absorbance of CMNO nanomaterials were evaluated by using Thermo Scientific NICOLET ISSO FTIR (Thermo Scientific spectrometer). The phase crystallinity and grain size of CMNO NMs were evaluated by XRD analysis. Band-gap energy was calculated for CMNO NMs by using UV-visible spectroscopy. The proposed sensor for selective creatine was fabricated with CMNO NMs onto GCE with a conducting binding agent (5\% Nafion). It was used to detect the CA in the phosphate buffer medium successively. To fabricate the sensor, Keithley electrometer (6517A, Chicago IL, USA) is used as the source of constant potential supply to analyze the current response with the injected analyte by fabricated sensor probe. It is stated that the fabricated sensor is analyzed with the two electrodes systems.

\subsection{Synthesis of CMNO Nanomaterials}

For the synthesis of $\mathrm{CMNO} N M s, \mathrm{NiSO}_{4} \cdot 6 \mathrm{H}_{2} \mathrm{O}, \mathrm{MnSO}_{4} \cdot \mathrm{H}_{2} \mathrm{O}$, and $\mathrm{CuCl}_{2} \cdot 2 \mathrm{H}_{2} \mathrm{O}$ were used to prepare $0.1 \mathrm{M}$ solutions of each in three different volumetric flasks of $100.0 \mathrm{~mL}$ in deionized water, and $50.0 \mathrm{~mL}$ of obtained solution from each flask taken into a $250.0 \mathrm{~mL}$ beaker. Then, the beaker kept on a hot heater at $80^{\circ} \mathrm{C}$ facilitated a magnetic stirring system. After this, the prepared $0.1 \mathrm{M} \mathrm{NH}_{4} \mathrm{OH}$ alkaline solution was added dropwise into the beaker to raise $\mathrm{pH}$ up-to 10.5. Due to the addition of the alkali solution, the $\mathrm{pH}$ increased, and metal ions precipitated as metal-hydroxides. It assumed that the metal ions precipitated quantitatively as $\mathrm{Cu}(\mathrm{OH})_{2} \cdot \mathrm{Mn}(\mathrm{OH})_{2} \cdot \mathrm{Ni}(\mathrm{OH})_{2}$ at $10.5 \mathrm{pH}$. The corresponding reactions are illustrated below.

$$
\begin{gathered}
\mathrm{NH}_{4} \mathrm{OH}_{(\mathrm{l})} \leftrightarrows \mathrm{NH}_{4}{ }^{+}{ }_{(\mathrm{aq})}+\mathrm{OH}^{-}{ }_{(\mathrm{aq})} \\
\mathrm{CuCl}_{2(\mathrm{~s})} \rightarrow \mathrm{Cu}^{2+}{ }_{(\mathrm{aq})}+2 \mathrm{Cl}^{-}{ }_{(\mathrm{aq})} \\
\mathrm{MnSO}_{4(\mathrm{~s})} \rightarrow \mathrm{Mn}^{2+}{ }_{(\mathrm{aq})}+\mathrm{SO}_{4}{ }^{2-}{ }_{(\mathrm{aq})} \\
\mathrm{NiSO}_{4(\mathrm{~s})} \rightarrow \mathrm{Ni}^{2+}{ }_{(\mathrm{aq})}+\mathrm{SO}_{4}{ }^{2-}{ }_{(\mathrm{aq})} \\
\mathrm{Cu}^{2+}{ }_{(\mathrm{aq})}+\mathrm{Mn}^{2+}{ }_{(\mathrm{aq})}+\mathrm{Ni}^{2+}{ }_{(\mathrm{aq})}+6 \mathrm{OH}^{-}{ }_{(\mathrm{aq})}+\mathrm{nH}_{2} \mathrm{O} \leftrightarrows \mathrm{Cu}(\mathrm{OH})_{2} \bullet \mathrm{Mn}(\mathrm{OH})_{2} \bullet \mathrm{Ni}(\mathrm{OH})_{2(\mathrm{~s})} \cdot \mathrm{nH}_{2} \mathrm{O} \downarrow
\end{gathered}
$$

After the completion of co-precipitation, the beaker was kept for several hours with magnetic stirring and the same temperature on the heater. Then the obtained nanomaterials were separated by filtration from reaction alkaline medium and followed by washing with deionized water successively. Then it kept an oven at $120^{\circ} \mathrm{C}$ overnight to dry. Next, the dry nanocrystals were subjected to calcine into a muffle furnace at $500{ }^{\circ} \mathrm{C}$ around $5 \mathrm{~h}$ in the flow of oxygen. The metal-hydroxides are oxidized and formed pure metal oxides. The reactions involved in the muffle furnace are as follows:

$$
\mathrm{Cu}(\mathrm{OH})_{2} \cdot \mathrm{Mn}(\mathrm{OH})_{2} \cdot \mathrm{Ni}(\mathrm{OH})_{2(\mathrm{~s})}+\mathrm{O}_{2} \rightarrow \mathrm{CuO} \cdot \mathrm{NiO} \cdot \mathrm{Mn}_{2} \mathrm{O}_{3}+3 \mathrm{H}_{2} \mathrm{O}_{(\mathrm{v})}
$$




\subsection{Fabrication of GCE by CMNO Nanomaterials}

The fabrication of GCE was a sensitive and important part of this research work for the detection of CA. At the beginning of the modification process, a slurry of CMNO NMs $(0.05 \mathrm{mg})$ in ethanol had been prepared and very carefully deposited/layered on the flat surface of GCE to form a thin-film of nano-formulated CMNO NMs. Then it was kept in the laboratory at ambient temperature to dry the surfaces. As per the requirement of this study, adequate stability of the CMNO NMs deposited layer onto GCE was required. Therefore, $0.1 \mu \mathrm{L}$ Nafion as an adhesive was added onto the CMNO fabricated layer to make the final modification of GCE. This was placed in an oven at $35^{\circ} \mathrm{C}$ for an hour to dry it completely. As a result, the modified GCE was found more stable in an aqueous medium during the electrochemical investigation. The proposed sensor was measured through an electrometer (Keithley electrometer, 6517A, Chicago IL, USA) by connecting the CMNO NMs/GCE as working and Pt-wire as the counter electrodes. To characterize the electrochemical performances of the chemical sensor, the $\mathrm{CA}$ was diluted in deionized water to make various solutions, ranging serially from $1.0 \mathrm{mM}$ to $0.1 \mathrm{nM}$. A calibration plot (plotted from the current versus concentration of CA) was used to estimate the analytical performances of the proposed CA sensor, including selectivity, LDR, and DL. During the I-V measurement, the phosphate buffer solution in the measuring electrochemical cell was kept constant as $10.0 \mathrm{~mL}$ throughout each experiment.

\section{Results and Discussions}

\subsection{Characterization of CMNO Nanomaterials}

To investigate the empirical formula and binding energies of atoms that existing in the nano-formulated CMNO NMs, the XPS analysis was executed and presented in Figure 1. The resulting XPS spectrum showed the peaks corresponding with $\mathrm{Cu}, \mathrm{Ni}, \mathrm{O}$ and $\mathrm{Mn}$ elements. The illustrated $\mathrm{Cu} 2 \mathrm{p}$ spin-orbit shows two peaks at 933.2 and $953.5 \mathrm{eV}$ with respect to $\mathrm{Cu} 2 \mathrm{p}_{3 / 2}$ and $\mathrm{Cu} 2 \mathrm{p}_{1 / 2}$ in $\mathrm{CuO}$ having a separation of $20.3 \mathrm{eV}$, which is shown in Figure 1a. This value of spin energy separation confirms the existence of $\mathrm{Cu}^{2+}$ oxidation in prepared nanomaterials [38,39]. A peak of O1s at $532.0 \mathrm{eV}$ illustrates in Figure $1 \mathrm{~b}$ and can be defined as the lattice oxygen with the ionization $\mathrm{O}^{2-}$ in sample CMNO NMs [40,41].

Figure $1 \mathrm{c}$ represents the high-resolution of the Ni2p spectrum. The obtained peaks are found at 856.3 and $874.1 \mathrm{eV}$ for $\mathrm{Ni} 2 \mathrm{p}_{3 / 2}$ and $\mathrm{Ni} 2 \mathrm{p}_{1 / 2}$ spin orbitals, respectively, which has an energy difference of $17.8 \mathrm{eV}$. Similarly, two satellite peaks of Ni2p level are assigned as $863.0 \mathrm{eV}$ for $\mathrm{Ni} 2 \mathrm{p} 3 / 2$ and $880.7 \mathrm{eV}$ for $\mathrm{Ni} 2 \mathrm{p}_{1 / 2}$, respectively, and the binding energy deterrence between these two satellite peaks of Ni2P is $17.7 \mathrm{eV}$. Therefore, the satellites and original peaks positions of Ni2p confirm the existence of $\mathrm{Ni}^{2+}$ ionization $[42,43]$. As demonstrated in Figure 1d, the Mn2p XPS spectrum shows the two peaks located at $641.3 \mathrm{eV}$ for $\mathrm{Mn} 2 \mathrm{p}_{3 / 2}$ and $653.0 \mathrm{eV}$ for $\mathrm{Mn} 2 \mathrm{p}_{1 / 2}$, respectively. The binding energy difference of Ni2p level is $11.7 \mathrm{eV}$, which is a characteristic value representing the oxidation state of $\mathrm{Mn}^{3+}$. An associated satellite peak for Mn2p illustrates in Figure 1d at $643.0 \mathrm{eV}$, which is responsible for the oxidation state of $\mathrm{Mn}^{4+}$. Therefore, the average oxidation state of Mn confirms from Mn3s orbit, which is demonstrated in Figure 1e. The spin energy separation in Mn2s orbit is shown at $3.0 \mathrm{eV}$. Therefore, it can predict that the average ionization of $\mathrm{Mn}$ is +3 [44-47].

To investigate the structural shape of prepared CMNO NMs, FESEM analysis was performed as the low to high-resolution images of FESEM represent in Figure 2a,b. As shown in Figure 2a,b, the molecule of metal oxides aggregate in an irregular way to form nanomaterial in shape. According to the EDS analysis report in Figure 2c, a similar result was repeated. The elemental compositions obtained from the EDS report, as illustrated in Figure 2d, are Mn (2.77\%), O (44.23\%), Ni $(11.49 \%)$, and $\mathrm{Cu}(41.51 \%)$ as a weight percentage. 

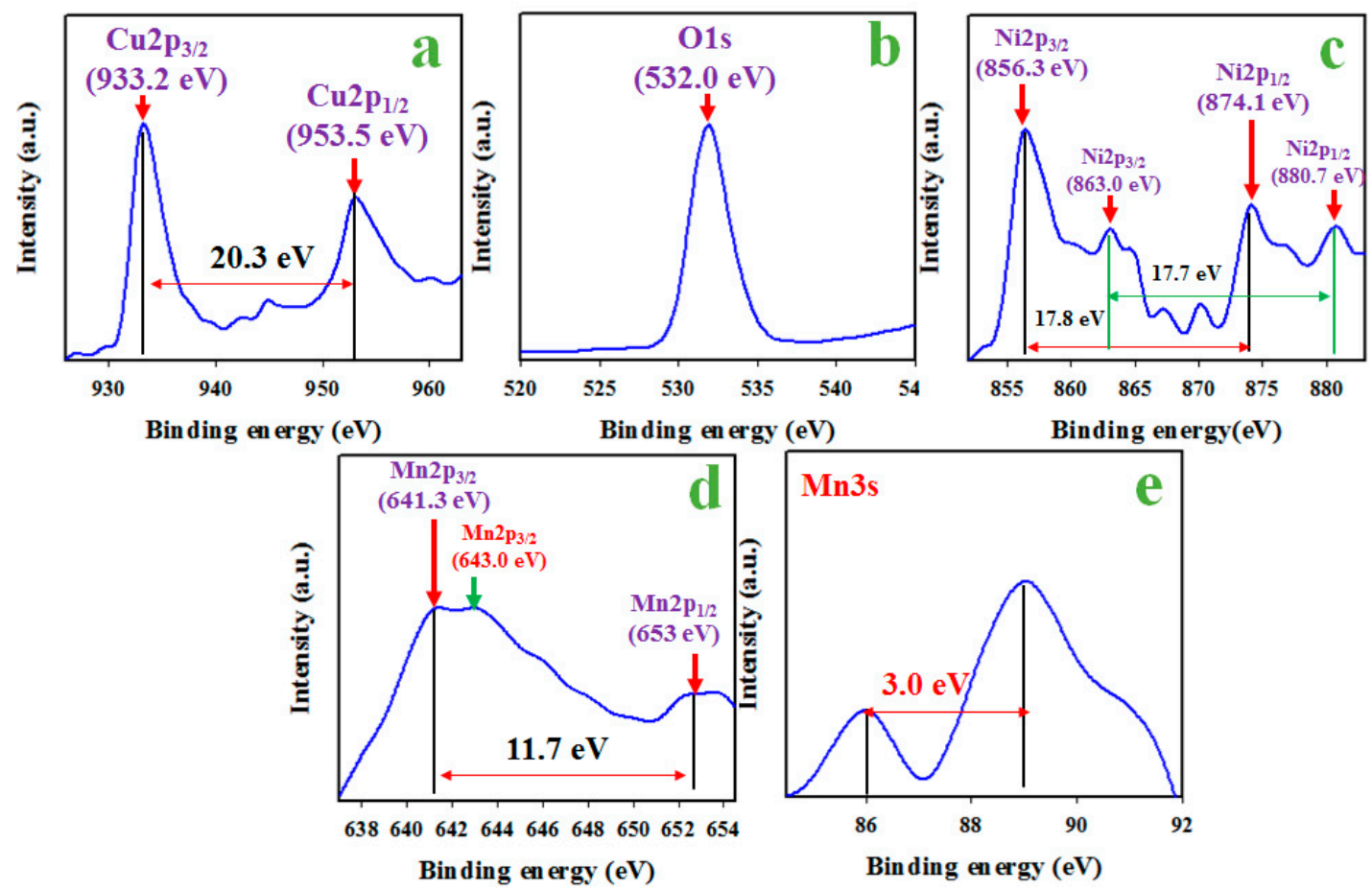

Figure 1. XPS analysis of low-dimensional nano-formulated porous mixed metal oxide nanomaterials (CMNO NMs) by X-ray photoelectron spectroscopy. The XPS spectrum of (a) spin-orbital of Cu2p level, (b) O1s orbit, (c) high-resolution XPS spectrum of Ni2p level, and (d) Mn2p spin orbits and (e) Mn3s level.
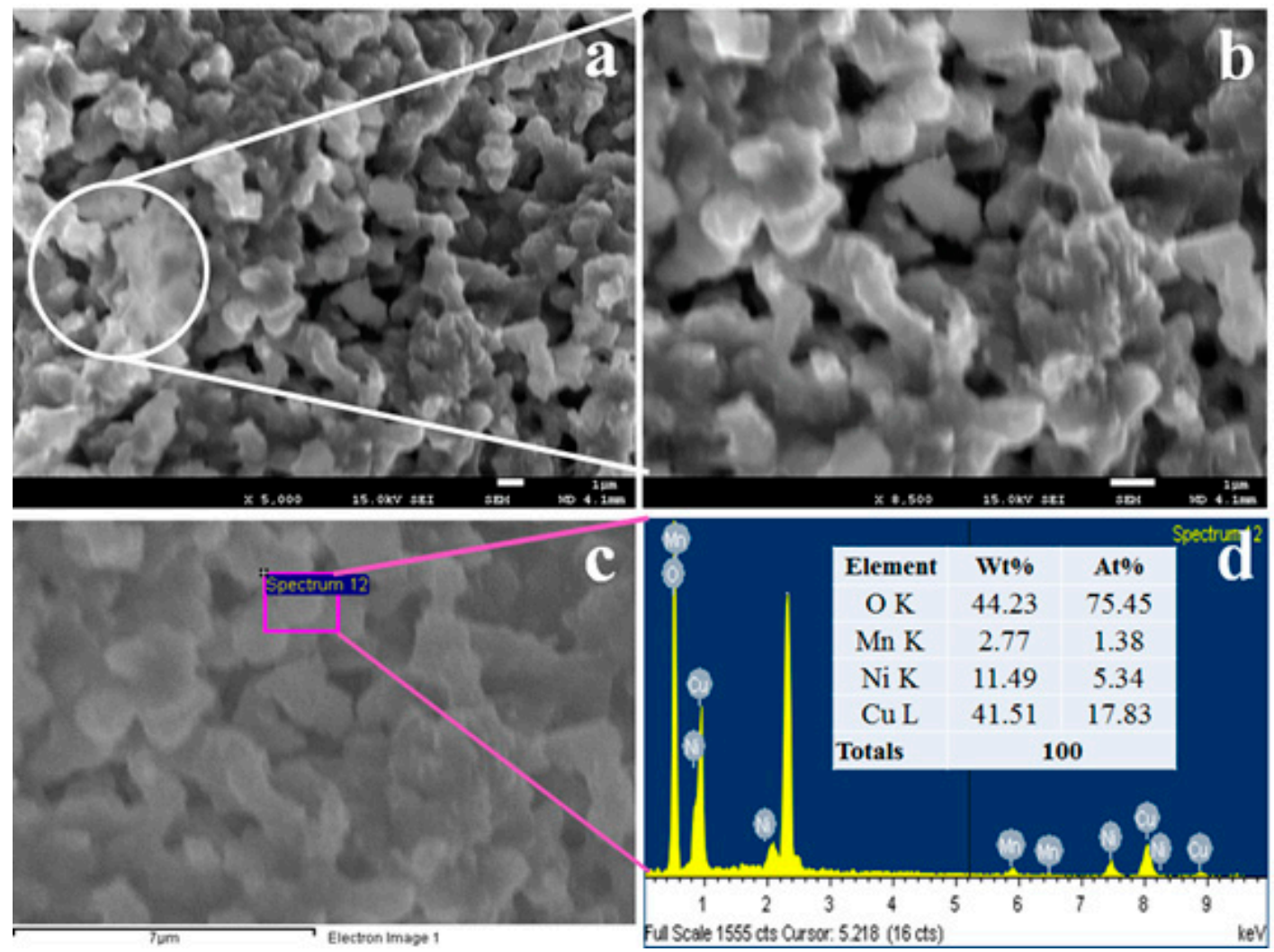

Figure 2. The FESEM and EDS analyses of CMNO nanomaterials. (a,b) The structural morphology of synthesized CMNO nanomaterials and $(\mathbf{c}, \mathbf{d})$ the elemental analysis of prepared CMNO NMs. 
XRD analysis was performed to identify the phase crystallinity of synthesized CMNO NMs. The XRD pattern shows the several peaks of $\mathrm{CuO}$ as (110), (202), and (020) are illustrated in Figure 3a, which matched with the JCPDS no 048-1548 [48,49]. The crystalline phases of $\mathrm{Mn}_{2} \mathrm{O}_{3}$ such (211), (222), (400), and (440) are identified in the XRD spectrum, which is illustrated in Figure 3a. The resultant planes of $\mathrm{Mn}_{2} \mathrm{O}_{3}$ are found similar to JCPDS no 041-1442 [50,51]. The NiO shows less intensive peaks of (200) and (220) as presented in Figure 3a, which is matched in JCPDS no. 047-1049 [52,53]. The average grain size of CMNO NMs is estimated by applying Debye-Scherer's formula according to Equation (7). It is found to be $10.71 \mathrm{~nm}$ at peak $\mathrm{Mn}_{2} \mathrm{O}_{3}$ (211).

$$
\mathrm{D}=0.9 \lambda /(\beta \cos \theta)
$$
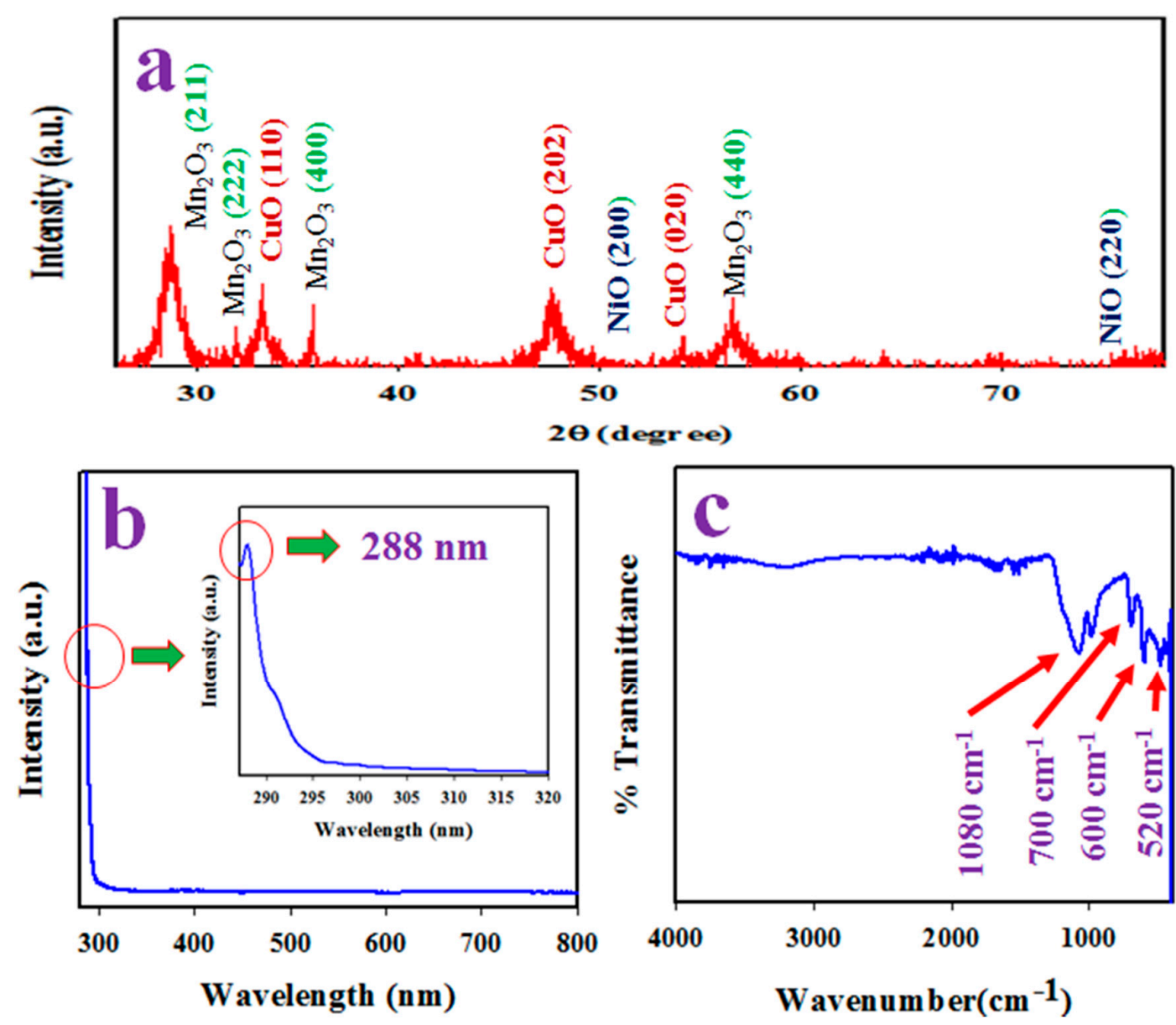

Figure 3. XRD, UV-vis and FTIR analysis of CMNO nanomaterials. (a) Crystallinity of CMNO NMs by XRD analysis, (b) UV-vis absorbance analysis and (c) the existing functional group investigation using FTIR analysis.

Here, $\lambda$ is the wavelength of $X$-ray radiation $\left(1.5418 \mathrm{~A}^{\circ}\right), \beta$ is full width at half (FWHM) of the peak at diffracted angle $\theta$.

To measure the band-gap energy, the synthesized CMNO nanomaterial was analyzed by UV-visible spectroscopy in the range of $265 \mathrm{~nm}$ to $800 \mathrm{~nm}$, which is presented in Figure 3b. As shown in Figure 3b, an absorption band was found at $288.0 \mathrm{~nm}$, which corresponds to the band-gap energy of $4.31 \mathrm{eV}$ [54,55]. This was calculated from Tauc's Equation $\left(\mathrm{E}_{\mathrm{bg}}=1240 / \lambda_{\max }\right)$. The functional groups existing of prepared CMNO NMs were identified by FTIR analysis in the range of 400 to $4000 \mathrm{~cm}^{-1}$, which was demonstrated in Figure 3c. Peaks at 520, 600, 700 and $1080 \mathrm{~cm}^{-1}$ were observed. The peak positioned at 520, 600, $700 \mathrm{~cm}^{-1}$ was described for the metal-oxygen (Cu-O, Ni-O and $\left.\mathrm{Mn}-\mathrm{O}\right)$ bond stretching vibration, 
and $1080 \mathrm{~cm}^{-1}$ was associated with $\mathrm{OH}$ - bending vibration [56,57]. The observed peaks at 600 and $700 \mathrm{~cm}^{-1}$ were responsible for bond stretching of $\mathrm{M}-\mathrm{O}$ bond formation [58].

\subsection{Application of $C A$ Sensor with $C M N O N M s / G C E$}

An electrochemical sensor for selective CA fabricated by using wet-chemically prepared CMNO nanomaterials was deposited onto GCE as a thin layer with 5\% Nafion adhesive. The purpose of using Nafion as a binder was not only to enhance the binding strength it also increased the conductivity and electron transfer rate of the prepared sensor [59,60]. Then, the assembled CA sensor based on CMNO NMs/GCE was subjected to detect CA in a phosphate buffer medium of $\mathrm{pH}$ 7.0. As per the literature search, CMNO NMs were applied for the first time to develop a CA sensor probe. No reports regarding this CA sensor probe development were found in any scientific report. In the electrochemical analysis of CA, the holding time on the Keithley electrometer was set as $1 \mathrm{~s}$ as constant throughout this study for the investigation of analytical parameters.

For the characterization of the fabricated sensor probe, several biochemicals were analyzed at $0.1 \mu \mathrm{M}$ concentration (similar concentration) in applied potential (Ranges: $0 \sim+1.5 \mathrm{~V}$ ) in a phosphate buffer medium ( $\mathrm{pH}$ 7.0). Figure 4a represents the electrochemical responses of D-glucose, folic acid, L(+)-lactic acid, cholesterol, choline, L(+)-aspartic acid, L-glutamic acid, dopamine, ascorbic acid, and finally CA. The CA shows the highest electrochemical response compared to other chemicals. Considering this highest electrochemical response of $\mathrm{CA}$, it is found as a selective chemical with the CMNO sensor probe by using the electrochemical method. It is not logical that the CMNO NMs layer onto GCE will show the equal electrochemical activities in the phosphate buffer solutions of all $\mathrm{pH}$ values in the presence of $\mathrm{CA}$. Therefore, the $\mathrm{pH}$ optimization of the buffer is necessary to obtain the maximum $\mathrm{I}-\mathrm{V}$ response in this electrochemical analysis. The $\mathrm{pH}$ optimization performances were investigated in the range of $\mathrm{pH}(5.7-8.0)$ of the buffer solutions, which is presented in Figure $4 \mathrm{~b} . \mathrm{pH} 7.0$ is found as optimum for CMNO NMs on GCE in the electrochemical analysis of CA, which is compared to another $\mathrm{pH}$.

Then, the CA sensor with CMNO NMs/GCE was applied to the analysis of CA in a range of $1.0 \mathrm{mM}$ to $0.1 \mathrm{nM}$ (Potential: $0 \sim+1.5 \mathrm{~V}$ ) presented in Figure 4c. As obtained in Figure 4c, the electrochemically analyzed data of CA is increased with the enhancement of CA concentration. The I-V outcomes are found distinct, which is gradually enhanced from low to a high concentration of CA. The comparative result has been cited previously in the electrochemical detection of various chemicals and bio-chemicals [61,62]. The calibration of the CA sensor is executed in Figure $4 \mathrm{~d}$ by applying the current data from Figure $4 \mathrm{c}($ Potential $+1.5 \mathrm{~V})$. This current versus CA concentration plot is found linear over the concentration of $0.1 \mathrm{nM}$ to $0.1 \mathrm{mM}$, which is denoted as the linear dynamic range (LDR) of CA detection in the phosphate buffer solution. As illustrated in Figure 4d, the current density data are regularly distributed on the line of the calibration plot. These outcomes provide good evidence about the reliability of the method. Thus, the obtained LDR is found really wider ranges for CA detection. The slope of LDR and active surface area of GCE $\left(0.0316 \mathrm{~cm}^{2}\right)$ were used to calculate the CA sensor sensitivity as $14.6308 \mu \mathrm{A} \mu \mathrm{M}^{-1} \mathrm{~cm}^{-2}$. It is found very good sensitivity value with this fabricated sensor probe with nano-formulated materials. The detection limit of the CA sensor is obtained using a signal/noise $(\mathrm{S} / \mathrm{N})$ ratio of 3 , which is equal to $21.63 \pm 0.2 \mathrm{pM}$. It is also found very good results with CMNO NMs/GCE sensor. The linearity $\left(\mathrm{r}^{2}\right)$ of the calibration curve is calculated and found as 0.9995 . The root-mean-square error (RMSE in LDR; $0.1 \mathrm{nM}$ to $0.1 \mathrm{mM}$ ) is calculated and found as $0.001897(\mathrm{uA})$. On the other way, the RMSE value in the full concentration ranges $(0.1 \mathrm{nM}$ to $1.0 \mathrm{mM}$ ) is also calculated and found as $11.74138 \mathrm{uA}$.

The reproducibility parameter of a sensor is very important for the reliability of a sensor. Here CA sensor with CMNO NMs/GCE electrode is subjected to measure the reproducibility as well as repeatability. Therefore, this performance is executed in identical conditions in $0.1 \mu \mathrm{MCA}$ (Potential ranges: 0 +1.5 V), which is represented in Figure 5a. As shown in Figure 5a, the seven electrochemical analyses exhibited CA detection in successive $7 \mathrm{~h}$ in a day are indistinguishable and 
almost similar responses are found. These electrochemical analyses of CA with fabricated electrodes were not significantly changed by the PBS washing of each working electrode after individual analysis. The precision of this reproducibility parameter was measured by using the terminology of relative standard deviation (RSD), which found $0.73 \%$ at potential $+1.5 \mathrm{~V}$. It provides the information of high precision of reproducibility. Thus, this test informs that the CA sensor probe can perform reliably in the field of its real-time application. A similar test has been performed for an extended period of seven days, which is illustrated in Figure 5b. The analogous information is obtained from Figure $5 \mathrm{a}$. Thus, the evidence of this test has confirmed the long-life of the working electrode of the CA sensor (CMNO NMs/GCE) in the PBS solution. Human serum is generally contained some common ions like $\mathrm{K}^{+}, \mathrm{Na}^{+}, \mathrm{Ca}^{2+}, \mathrm{Mg}^{2+}$. The influences of these ions are considered in the electrochemical analyses of CA. Therefore, the CA was analyzed electrochemically in the presence of these common ions, as illustrated in Figure 5c. It can be concluded from the outcome of Figure 4c that the CA sensor has not any interfering effect of these ions in the detection of CA with CMNO NMs/GCE sensor. The response time provides information on the efficiency of a sensor probe. This test is done at $0.1 \mu \mathrm{MCA}$ in the buffer solution of $\mathrm{pH} 7.0$, which is demonstrated in Figure $5 \mathrm{~d}$. As it has seemed from Figure $5 \mathrm{~d}$, an efficient result of response time around $30.0 \mathrm{~s}$ is obtained.
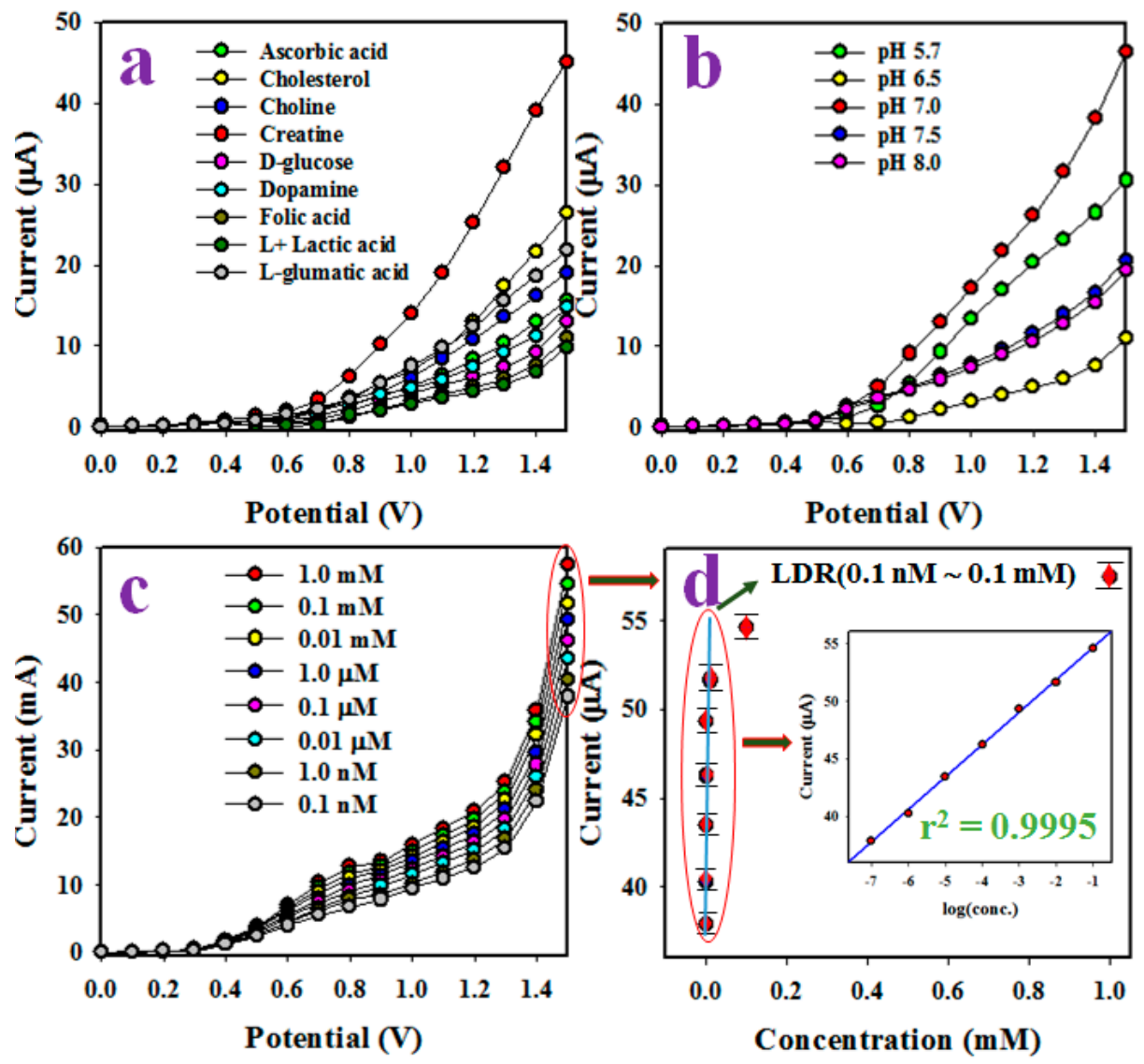

Figure 4. Characterization and evaluation of analytical performances of CMNO sensor probe for the detection of creatine (CA) chemical. (a) Selectivity analysis, (b) pH optimization, (c) electrochemical responses based on concentration variation of CA solution, and (d) calibration curve. Inset ((log (conc.) vs. current).

The proposed CA sensor probe was fabricated, and sensor performance was compared with ternary mixed metal oxides as well as single and binary counterparts $\left(\mathrm{CuO}, \mathrm{Mn}_{2} \mathrm{O}_{3}, \mathrm{NiO}, \mathrm{Mn}_{2} \mathrm{O}_{3} / \mathrm{NiO}\right.$, $\mathrm{CuO} / \mathrm{Mn}_{2} \mathrm{O}_{3}$ ). Control experiments were performed to explain the uses of such various combinations. As illustrated in Figure 6a, the GCE was modified with single metal oxides $\left(\mathrm{CuO}, \mathrm{Mn}_{2} \mathrm{O}_{3}\right.$, and $\left.\mathrm{NiO}\right)$ and subjected to electrochemical analysis with $0.1 \mu \mathrm{M}$ CA detection in PBS ( $\mathrm{pH}$ 7.0). As perceived in 
Figure 6a, the single metal oxides are exhibited the lower electrochemical responses, which compared to $\mathrm{CMNO}$ in the detection of CA. On the other hand, the binary mixture of metal oxides such as $\mathrm{CuO} / \mathrm{Mn}_{2} \mathrm{O}_{3} \mathrm{NMs}$ and $\mathrm{Mn}_{2} \mathrm{O}_{3} / \mathrm{NiO} \mathrm{NMs}$ show a higher electrochemical response compared to their single metallic oxide. Finally, the ternary mixture of metal oxides (CMNO NMs) shows the highest electrochemical response compared to the single and binary-modified GCE due to the large and active surface area of CMNO.

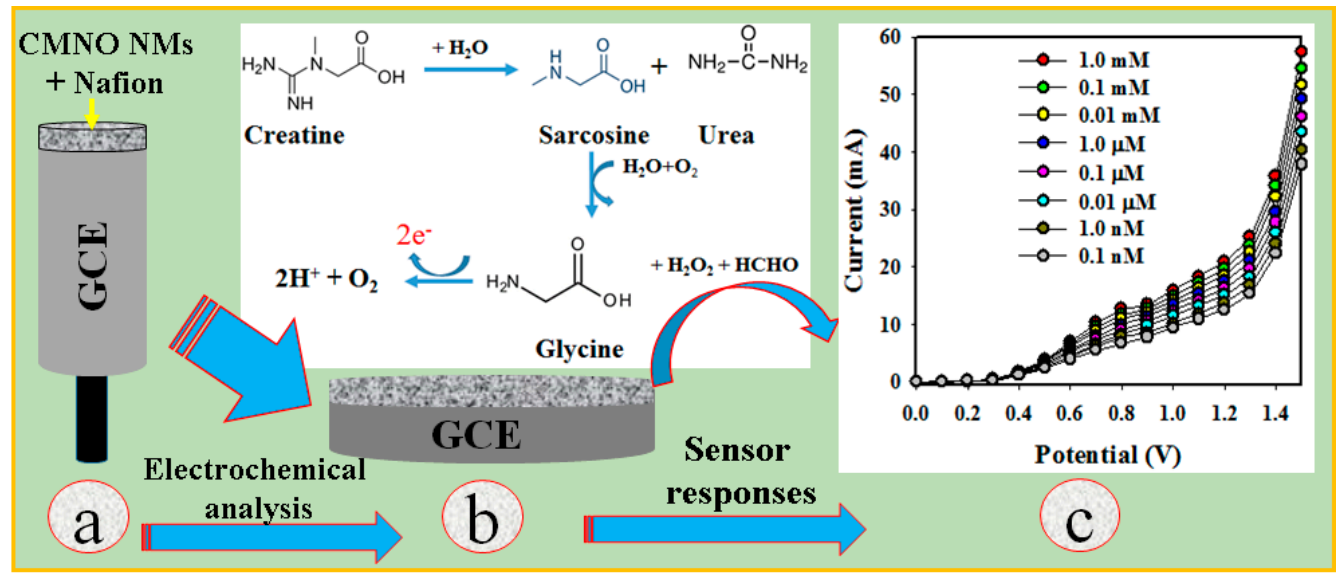

Scheme 1. Schematic representation of CA sensing CMNO NMs/GCE. (a) Modification of glassy carbon electrode (GCE) with CMNO NMs, (b) electrochemical oxidation of CA on CMNO NMs/GCE, and (c) responses recorded in electrometer.
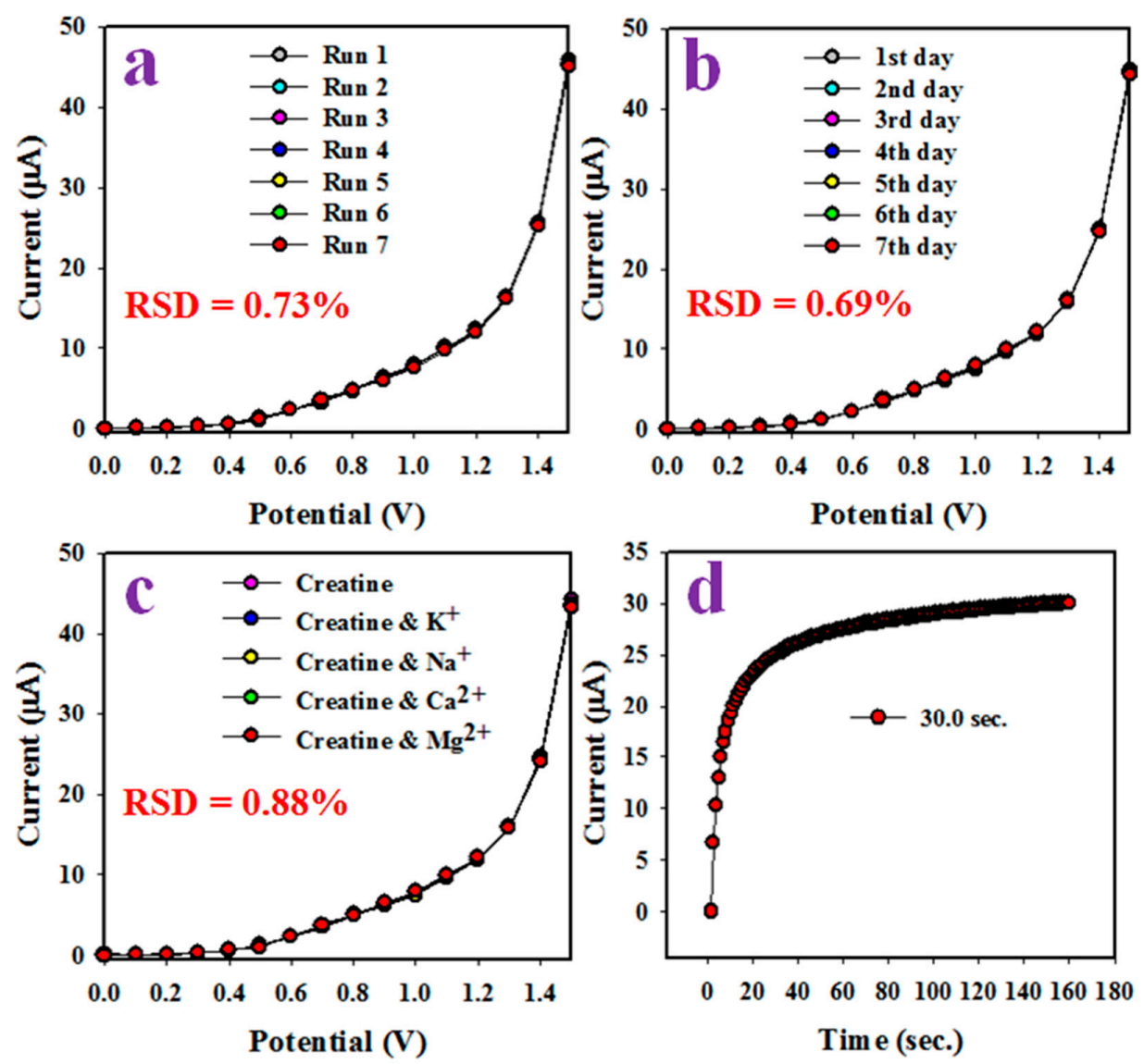

Figure 5. Optimization of the creatinine sensor. (a) Reducibility of the CA sensor, (b) validity of CA sensor around 7 days, (c) interference effect estimation in the presence of electrolytes and (d) response time. 

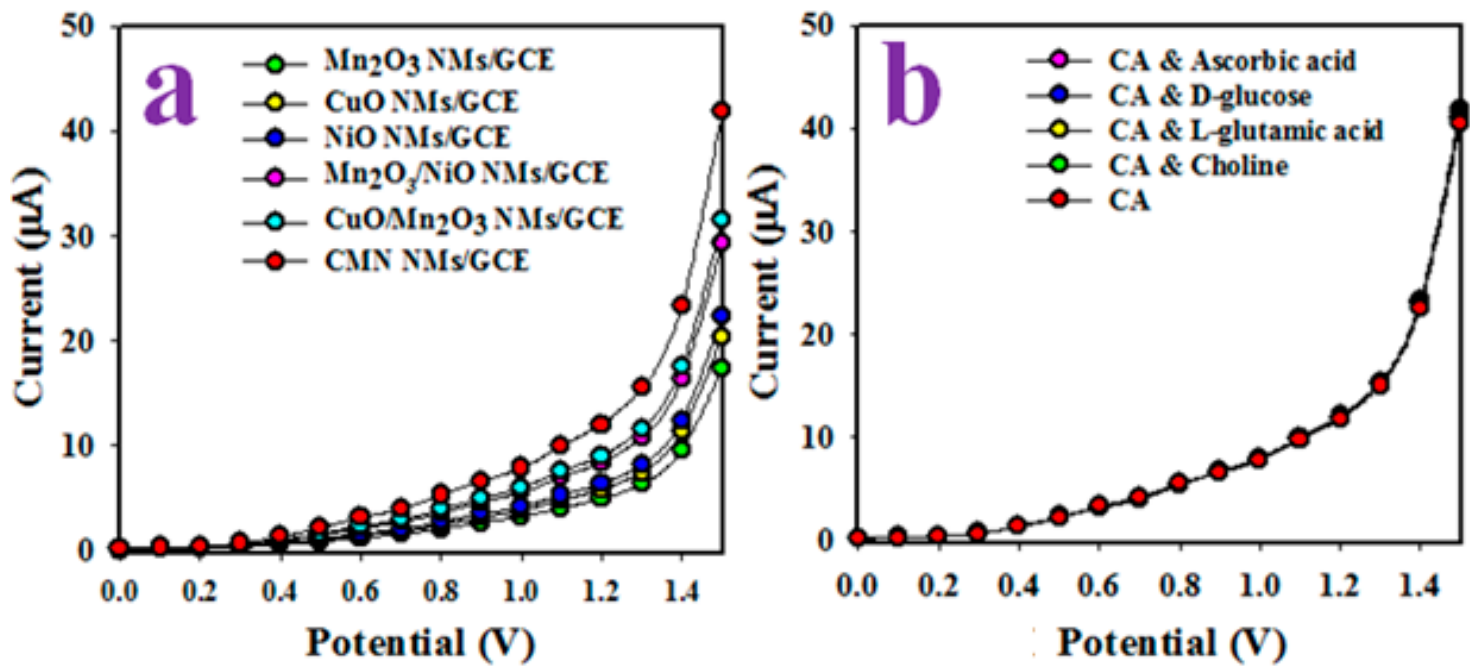

Figure 6. Optimization of the sensor probe. (a) Control experiments to evaluate the electrochemical activities of various NMs, and (b) interferences effect of sensor probe in the detection of CA with the presence of biochemical.

It is exhibited due to the combinational effects of ternary metal oxides. As a result, these ternary metal oxides decorated GCE showed a better sensitivity compare to single metal oxides, as presented in Table $1[64,65]$. It has been reported that the doped metal oxides have shown better electrochemical properties than the undoped metal oxide $[66,67]$. As reported previously, the reactive surface area of synthesized nanomaterials is increased significantly due to the doping of nanostructured materials [68-70]. This is the main fact to enhance the electrochemical activity of the fabricated CA sensor probe in the detection of target $\mathrm{CA}$. Another control experiment was performed to check the interference effect in the electrochemical analysis of CA in co-existence of other biochemical, as illustrated in Figure $6 \mathrm{~b}$. It is found that the co-existence of other biochemicals such as ascorbic acid, D-glucose, L-glutamic acid and choline with CA does not have any interference effect. Therefore, the CA sensor probe with $\mathrm{CMNO} \mathrm{NMs} / \mathrm{GCE}$ is selective to $\mathrm{CA}$ in electrochemical detection.

Table 1. Comparison of CMNO-fabricated sensor probe performances for the detection of CA based on different electrode fabrication by electrochemical approaches.

\begin{tabular}{ccccc}
\hline Modified GCE & ${ }^{*}$ DL & ${ }^{*}$ LDR & Sensitivity & Ref. \\
\hline CdO NP/GCE & $50.0 \mathrm{pM}$ & $0.1 \mathrm{nM} \sim 0.1 \mathrm{M}$ & $1.90 \mu \mathrm{A} \mu \mathrm{M}^{-1} \mathrm{~cm}^{-2}$ & {$[64]$} \\
ATO-NPs/Nafion/GCE & $42.0 \mathrm{pM}$ & $0.1 \mathrm{nM} \sim 1.0 \mathrm{mM}$ & $0.276 \mu \mathrm{A} \mathrm{M}^{-1} \mathrm{~cm}^{-2}$ & {$[65]$} \\
CMNO NMs/GCE & $21.63 \mathrm{pM}$ & $0.1 \mathrm{nM} \sim 0.1 \mathrm{mM}$ & $14.631 \mu \mathrm{A} \mu \mathrm{M}^{-1} \mathrm{~cm}^{-2}$ & This work \\
\hline
\end{tabular}

${ }^{*}$ DL (detection limit) and ${ }^{\#}$ LDR (linear dynamic range).

Shortly, it is concluded that the proposed CA sensor exhibited good and significant results in terms of sensitivity, LDR, and DL. Besides this, it was found as long-term stable with constant outcome in an identical condition in short response time. A comparison between similar research is represented in Table 1, in terms of sensitivity, linear dynamic range and detection limit $[64,65]$. It observes that the fabricated sensor probe is selective towards target CA in enzyme-less sensing with low-dimensional nano-formulated ternary CMNO NMs by using electrochemical methods, which related other reports in enzyme-less CA detection with different sensing matrixes such as nanomaterials or nanocomposites [71-79].

\subsection{Real Samples Analysis}

The CA sensor based on CMNO NMs/GCE was implemented for the analysis of various real biological samples such as mouse serum, human serum and rabbit serum. They were collected from the local medical store and used in accordance with ethical guidelines. Initially, the serum samples 
were separated and diluted (10 times) in the PBS buffer. The results are presented in Table 2. As it appears in Table 2, the analysis data were acceptable and in good agreement with the results.

Table 2. Analyses of real biological samples with CMNONMs/GCE sensor probe by electrochemical method.

\begin{tabular}{|c|c|c|c|c|c|c|}
\hline \multirow{2}{*}{$\begin{array}{l}\text { Real } \\
\text { Samples }\end{array}$} & \multirow{2}{*}{$\begin{array}{l}\text { Added CA } \\
\text { conc. }(\mu \mathrm{M})\end{array}$} & \multicolumn{3}{|c|}{$\begin{array}{c}\text { Measured CA conc. }{ }^{\mathrm{a}} \text { by CMNO NMs/GCE } \\
(\mu \mathrm{M})\end{array}$} & \multirow{2}{*}{$\begin{array}{c}\text { Average Recovery } \\
(\%)\end{array}$} & \multirow{2}{*}{$\begin{array}{c}\operatorname{RSD}^{\mathrm{c}}(\%) \\
(\mathrm{n}=3)\end{array}$} \\
\hline & & R1 & R2 & $\mathbf{R} 3$ & & \\
\hline $\begin{array}{l}\text { Mouse } \\
\text { serum }\end{array}$ & 0.01 & 0.00992 & 0.00996 & 0.00996 & 99.52 & 0.23 \\
\hline $\begin{array}{l}\text { Rabbit } \\
\text { serum }\end{array}$ & 0.01 & 0.00997 & 0.00994 & 0.00995 & 99.56 & 0.15 \\
\hline $\begin{array}{l}\text { Human } \\
\text { urine }\end{array}$ & 0.01 & 0.01179 & 0.01182 & 0.01165 & 117.54 & 0.77 \\
\hline
\end{tabular}

a Mean of three repeated determination (signal to noise ratio 3) with CMNO NMs/GCE. ${ }^{b}$ concentration of CA determined/concentration taken (unit: $\mathrm{nM}$ ). ${ }^{\mathrm{c}}$ relative standard deviation value indicates precision among three repeated measurements (R1, R2, R3).

\section{Conclusions}

Here, a selective chemical sensor was developed with enzyme-less CMNO NMs/GCE, which was used to detect selective $\mathrm{CA}$ in the phosphate buffer phase at $\mathrm{pH}$ 7.0. The good analytical parameters of cancer metabolic CA bio-marker sensor such as sensitivity, stability, reproducibility, linearity, linear dynamic range, and detection limit were measured, and the corresponding sensing results were found. Besides those, the target CMNO NMs/GCE sensor probe was validated and finally analyzed with biological samples such as a human serum, rabbit serum, mouse serum, human urine. It was obtained good results in this enzyme-free detection. Thus, the enzyme-less CMNO NMs/GCE sensor probe was exhibited good reproducibility in short response time, ultra-sensitivity, excellent selectivity, which provides a promising methodology for clinical cancer metabolic CA detection in biomedical and healthcare fields on a broad scales.

Author Contributions: Conceptualization, M.M.R. and A.M.A.; methodology, M.M.A.; validation, F.A.D.M.O. and M.M.R.; formal analysis, M.M.A.; investigation, M.M.R. and M.M.A.; resources, A.M.A.; data curation, M.M.A.; writing-original draft preparation, M.M.A. and M.M.R.; writing—review and editing, M.M.R.; supervision, A.M.A.; project administration, M.M.R. and F.A.D.M.O.; funding acquisition, M.M.R. All authors have read and agreed to the published version of the manuscript.

Funding: This research was funded by National Plan for Science, Technology and Innovation (MAARIFAH)—King Abdulaziz City for Science and Technol—the Kingdom of Saudi Arabia, grant number 14-BIO1978-03" and The APC was funded from the project "14-BIO1978-03".

Acknowledgments: This project was funded by the National Plan for Science, Technology and Innovation (MAARIFAH) - King Abdulaziz City for Science and Technol-the Kingdom of Saudi Arabia-award number (14-BIO1978-03). The authors also acknowledge with thanks the Science and Technology Unit, King Abdulaziz University, for technical support.

Conflicts of Interest: The authors declare no conflict of interest

\section{References}

1. Cooper, R.; Naclerio, F.; Allgrove, J.; Jimenez, A. Creatine supplementation with specific view to exercise/sports performance: An update. J. Int. Soc. Sports. Nutr. 2012, 9, 33. [CrossRef] [PubMed]

2. Brosnan, M.E.; Brosnan, J.T. The role of dietary creatine. Amino Acids 2016, 48, 1785-1791. [CrossRef] [PubMed]

3. Deminice, R.; da Silva, R.P.; Lamarre, S.G.; Brown, C.; Furey, G.N.; McCarter, S.A.; Jordao, A.A.; Kelly, K.B.; King-Jones, K.; Jacobs, R.L.; et al. Creatine supplementation prevents the accumulation of fat in the livers of rats fed a high-fat diet. J. Nutr. 2011, 141, 1799-1804. [CrossRef] [PubMed]

4. Walker, J.B. Creatine: Biosynthesis, regulation, and function. Adv. Enzymol. Relat. Areas Mol. Biol. 1979, 50, 177-242. [PubMed] 
5. Braissant, O.; Henry, H. AGAT, GAMT and SLC6A8 distribution in the central nervous system, in relation to creatine deficiency syndromes: A review. J. Inherit. Metab. Dis. 2008, 31, 230-239. [CrossRef] [PubMed]

6. Braissant, O.; Henry, H.; Beard, E.; Uldry, J. Creatine deficiency syndromes and the importance of creatine synthesis in the brain. Amino Acids 2011, 40, 1315-1324. [CrossRef]

7. Schulze, A. Creatine deficiency syndromes. Mol. Cell. Biochem. 2003, 244, 143-150. [CrossRef]

8. Masaru, S.; Mitsutaka, Y. A new enzymatic serum creatinine measurement based on an endogenous creatine-eliminating system. Clin. Chim. Acta 1984, 143, 147-155. [CrossRef]

9. Beyer, C.; Hoenderdos, A.; Mairuhu, W.M.; Statius, L.W. Evaluative and comparative study of an enzymatic method using creatine kinase for the determination of urinary creatine. Clin. Chim. Acta 1984, 136, 263-270. [CrossRef]

10. Chen, S.P.; Kuan, S.S.; Guilbault, G.G. Fluorometric enzymatic determination ofserum creatinine on the surface of silicone-rubber pads. Clin. Chim. Acta 1980, 100, 21-31.

11. Patel, D.P.; Pauly, G.T.; Tada, T.; Parker, A.L.; Toulabi, L.; Kanke, Y.; Oike, T.; Krausz, K.W.; Gonzalez, F.J.; Harris, C.C. Improved detection and precise relative quantification of the urinary cancer metabolite biomarkers-Creatine riboside, creatinine riboside, creatine and creatinine by UPLC-ESI-MS/MS: Application to the NCI-Maryland cohort population controls and lung cancer cases. J. Pharm. Biomed. Anal. 2020, 191, 113596. [PubMed]

12. Rahman, M.M.; Awual, M.R.; Asiri, A.M. Preparation and evaluation of composite hybrid nanomaterials for rare-earth elements separation and recovery. Sep. Purif. Technol. 2020, 253, 117515. [CrossRef]

13. Rahman, M.M.; Alam, M.M.; Asiri, A.M. Sensitive 1,2-dichlorobenzene chemi-sensor development based on solvothermally prepared $\mathrm{FeO} / \mathrm{CdO}$ nanocubes for environmental safety. J. Ind. Eng. Chem. 2018, 62, 392-400. [CrossRef]

14. Rahman, M.M.; Alam, M.M.; Asiri, A.M. 2-Nitrophenol sensor-based wet-chemically prepared binary doped Co3O4/A12O3 nanosheets by an electrochemical approach. RSC Adv. 2018, 8, 960-970. [CrossRef]

15. Rahman, M.M.; Alam, M.M.; Asiri, A.M.; Opo, F.A.D.M. Fabrication of selective and sensitive chemical sensor probe based on ternary nano-formulated $\mathrm{CuO} / \mathrm{MnO}_{2} / \mathrm{Gd}_{2} \mathrm{O}_{3}$ spikes by hydrothermal approach. Sci. Rep. 2020, 10, 20248. [CrossRef] [PubMed]

16. Alam, M.S.; Rahman, M.M.; Marwani, H.M.; Hasnat, M.A. Insights of temperature dependent catalysis and kinetics of electro-oxidation of nitrite ions on a glassy carbon electrode. Electrochim. Acta 2020, 362, 137102. [CrossRef]

17. Hussain, M.M.; Asiri, A.M.; Rahman, M.M. Non-enzymatic simultaneous detection of acetylcholine and ascorbic acid using ZnO.CuO nanoleaves: Real sample analysis. Microchem. J. 2020, 159, 105534. [CrossRef]

18. Rahman, M.M.; Adeosun, W.A.; Asiri, A.M. Fabrication of selective and sensitive chemical sensor development based on flower-flake $\mathrm{La}_{2} \mathrm{ZnO}_{4}$ nanocomposite for effective non-enzymatic Sensing of hydrogen peroxide by electrochemical method. Microchem. J. 2020, 159, 105536. [CrossRef]

19. Asiri, A.M.; Adeosun, W.A.; Rahman, M.M. Development of highly efficient non-enzymatic nitrite sensor using $\mathrm{La}_{2} \mathrm{CuO}_{4}$ nanoparticles. Microchem. J. 2020, 159, 105527. [CrossRef]

20. Ghanei-Motlagh, M.; Baghayeri, M. Determination of Trace Tl(I) by Differential Pulse Anodic Stripping Voltammetry Using a Novel Modified Carbon Paste Electrode. J. Electrochem. Soc. 2020, 167, 066508. [CrossRef]

21. Ghanei-Motlagh, M.; Taher, M.A.; Fayazi, M.; Baghayeri, M.; Hosseinifar, A. Non-Enzymatic Amperometric Sensing of Hydrogen Peroxide Based on Vanadium Pentoxide Nanostructures. J. Electrochem. Soc. 2019, 166, B367-B372. [CrossRef]

22. Rouhi, M.; Lakouraj, M.M.; Baghayeri, M. Low Band Gap Conductive Copolymer of Thiophene with p-Phenylenediamine and Its Magnetic Nanocomposite: Synthesis, Characterization and Biosensing Activity. Polym. Compos. 2019, 40, 1034-1042. [CrossRef]

23. Nodehi, M.; Baghayeri, M.; Ansari, R.; Veisi, H. Electrochemical quantification of $17 \alpha-$ Ethinylestradiol in biological samples using a $\mathrm{Au} / \mathrm{Fe}_{3} \mathrm{O}_{4} @ \mathrm{TA} / \mathrm{MWNT} / \mathrm{GCE}$ sensor. Mater. Chem. Phys. 2020, 244, 122687. [CrossRef]

24. Baghayeri, M.; Ghanei-Motlagh, M.; Tayebee, R.; Fayazi, M.; Narenji, F. Application of graphene/zinc-based metal-organic framework nanocomposite for electrochemical sensing of As(III) in water resources. Anal. Chim. Acta 2020, 1099, 60-67. [CrossRef] [PubMed] 
25. Baghayeri, M.; Ansari, R.; Nodehi, M.; Razavipanah, I.; Veisi, H. Label-free Electrochemical Bisphenol A Aptasensor Based on Designing and Fabrication of a Magnetic Gold Nanocomposite. Electroanalysis 2018, 30, 2160-2166. [CrossRef]

26. Baghayeri, M.; Ansari, R.; Nodehi, M.; Razavipanah, I.; Veisi, H. Voltammetric aptasensor for bisphenol A based on the use of a MWCNT/Fe ${ }_{3} \mathrm{O}_{4} @$ gold nanocomposite. Microchim. Acta 2018, 185, 320. [CrossRef]

27. Rahman, M.M.; Alam, M.M.; Asiri, A.M.; Awual, M.R. Fabrication of 4-aminophenol sensor based on hydrothermally prepared $\mathrm{ZnO} / \mathrm{Yb}_{2} \mathrm{O}_{3}$ nanosheets. New J. Chem. 2017, 41, 9159-9169. [CrossRef]

28. Rahman, M.M.; Alam, M.M.; Asiri, A.M.; Islam, M.A. Ethanol sensor development based on ternarydoped metal oxides (CdO/ZnO/Yb2O3) nanosheets for environmental safety. RSC Adv. 2017, 7, 22627-22639. [CrossRef]

29. Rahman, M.M.; Alam, M.M.; Asiri, A.M.; Islam, M.A. Fabrication of selective chemical sensor with ternary $\mathrm{ZnO} / \mathrm{SnO} 2 / \mathrm{Yb} 2 \mathrm{O} 3$ nanoparticles. Talanta 2017, 170, 215-223. [CrossRef]

30. Zoolfakar, A.S.; Rani, R.A.; Morfa, A.J.; O’Mullaned, A.P.; Kalantar-zadeh, K. Nanostructured Copper Oxide Semiconductors: A Perspective on Materials, Synthesis methods and Applications. J. Mater. Chem. C 2014, 2, 5247-5270. [CrossRef]

31. Grigore, M.E.; Biscu, E.R.; Holban, A.M.; Gestal, M.C.; Grumezescu, A.M. Methods of Synthesis, Properties and Biomedical Applications of CuO Nanoparticles. Pharmaceuticals 2016, 9, 75. [CrossRef] [PubMed]

32. Sheikh, T.A.; Rahman, M.M.; Asiri, A.M.; Marwani, H.M. Sensitive 3-chlorophenol sensor development based on facile Er2O3/CuO nanomaterials for environmental safety. New J. Chem. 2018, 42, 3936-3946. [CrossRef]

33. Rahman, M.M.; Asiri, A.M. Development of selective and sensitive bicarbonate chemical sensor based on wet-chemically prepared CuO-ZnO nanorods. Sens. Actuators B Chem. 2015, 214, 82-91. [CrossRef]

34. ul Haque, S.; Nasar, A.; Rahman, M.M. Applications of chitosan (CHI)-reduced graphene oxide (rGO)-polyaniline (PAni) conducting composite electrode for energy generation in glucose biofuel cell. Sci. Rep. 2020, 10, 10428. [CrossRef] [PubMed]

35. Sharma1, S.; Chauhan, P.; Husain, S. Structural and optical properties of Mn2O3 nanoparticles \& its gas sensing applications. Adv. Mater. Process. 2016, 1, 220-225.

36. Sharrouf, M.; Awad, R.; Roumié, M.; Marhaba, S. Structural, Optical and Room Temperature Magnetic Study of Mn2O3 Nanoparticles. Mater. Sci. Appl. 2015, 6, 850-859.

37. Sone, B.T.; Fuku, X.G.; Maaza, M. Physical \& Electrochemical Properties of Green Synthesized Bunsenite $\mathrm{NiO}$ Nanoparticles via Callistemon Viminalis' Extracts. Int. J. Electrochem. Sci. 2016, 11, 8204-8220.

38. Amor, M.B.; Hamzaoui, N.; Boukhachem, A.; Mrabet, C.; Ghamnia, M.; Yumak, A.; Boubaker, K.; Petkova, P.; Amlouk, M. Optical, Physical, Chemical and Electrical Properties of Nickel Oxide Sprayed Thin Films under Tin Doping Effects. Adv. Ceram. Sci. Eng. (ACSE) 2015, 24, 72-76. [CrossRef]

39. Jin, Z.; Liu, C.; Qi, K.; Cui, X. Photo-reduced $\mathrm{Cu} / \mathrm{CuO}$ nanoclusters on $\mathrm{TiO}_{2}$ nanotube arrays as highly efficient and reusable catalyst. Sci. Rep. 2017, 7, 39695. [CrossRef]

40. Chen, R.X.; Zhu, S.L.; Mao, J.; Cui, Z.D.; Yang, X.J.; Liang, Y.Q.; Li, Z.Y. Synthesis of CuO/Co3O4 Coaxial Hetero-structures for Efficient and Recycling Photo degradation. Int. J. Photoenergy 2015, 1, 1-11.

41. Rahman, M.M.; Gruner, G.; Al-Ghamdi, M.S.; Daous, M.A.; Khan, S.B.; Asiri, A.M. Chemo-sensors development based on low-dimensional codoped $\mathrm{Mn} 2 \mathrm{O} 3-\mathrm{ZnO}$ nanoparticles using flat-silver electrodes. Chem. Cent. J. 2013, 7, 60. [CrossRef] [PubMed]

42. Rahman, M.M.; Khan, S.B.; Marwani, H.M.; Asiri, A.M.; Alamry, K.A. Selective Iron (III) ion uptake using $\mathrm{CuO}-\mathrm{TiO} 2$ nanostructure by inductively coupled plasma-optical emission spectrometry. Chem. Cent. J. 2012, 6, 158. [CrossRef] [PubMed]

43. Zhu, D.; Guo, C.; Liu, J.; Wang, L.; Dub, Y.; Qiao, S.Z. Two-dimensional metal-organic frameworks with high oxidation states for efficient electrocatalytic urea oxidation. Chem. Commun. 2017, 53, 10906-10909. [CrossRef] [PubMed]

44. Kalaiyarasan, G.; Aswathi, K.; Joseph, J. Formation of nanoporous NiS films from electrochemically modified GC surface with Nickel Hexacyanoferrate film and its performance for the hydrogen evolution reaction. Int. J. Hydrogen Energy 2017, 42, 22866-22876. [CrossRef]

45. Huang, M.; Zhang, Y.; Li, F.; Wang, Z.; Hu, N.; Wen, Z.; Liu, Q. Merging of Kirkendall Growth and Ostwald Ripening: CuO@MnO2 Core-shell Architectures for Asymmetric Supercapacitors. Sci. Rep. 2016, 4, 4518. [CrossRef] 
46. Wang, X.; Wu, W.; Chen, Z.; Wang, R. Bauxite-supported Transition Metal Oxides: Promising Low-temperature and SO2-tolerant Catalysts for Selective Catalytic Reduction of NOx. Sci. Rep. 2015, 5, 9766. [CrossRef]

47. Xia, H.; Zhu, D.; Luo, Z.; Yu, Y.; Shi, X.; Yuan, G.; Xie, J. Hierarchically Structured Co3O4@Pt@MnO2 Nanowire Arrays for High-Performance Supercapacitors. Sci. Rep. 2013, 3, 2978. [CrossRef]

48. Ethiraj, A.S.; Kang, D.J. Synthesis and characterization of $\mathrm{CuO}$ nanowires by a simple wet chemical method. Nanoscale Res. Lett. 2012, 7, 70. [CrossRef]

49. Suleiman, M.; Mousa, M.; Hussein, A.I.A. Wastewater Disinfection by Synthesized Copper Oxide Nanoparticles Stabilized with Surfactant. J. Mater. Environ. Sci. 2015, 6, 1924-1937.

50. Li, Z.Y.; Akhtar, M.S.; Bui, P.T.M.; Yang, O.B. Predominance of two dimensional (2D) Mn2O3 nanowalls thin film for high performance electrochemical supercapacitors. Chem. Eng. J. 2017, 330, 1240-1247. [CrossRef]

51. Ashouri, F.; Zare, M.; Bagherzadeh, M. Manganese and cobalt-terephthalate metal-organic frameworks as a precursor for synthesis of $\mathrm{Mn}_{2} \mathrm{O}_{3}, \mathrm{Mn}_{3} \mathrm{O}_{4}$ and $\mathrm{Co}_{3} \mathrm{O}_{4}$ nanoparticles: Active catalysts for olefin heterogeneous oxidation. Inorg. Chem. Commun. 2015, 61, 73-76. [CrossRef]

52. Yan, H.; Zhang, D.; Xu, J.; Lu, Y.; Liu, Y.; Qiu, K.; Zhang, Y.; Luo, Y. Solution growth of NiO nanosheets supported on Ni foam as high-performance electrodes for supercapacitors. Nanoscale Res. Lett. 2014, 9, 424. [CrossRef] [PubMed]

53. Yung, T.Y.; Huang, L.Y.; Chan, T.Y.; Wang, K.S.; Liu, T.Y.; Chen, P.T.; Chao, C.Y.; Liu, L.K. Synthesis and characterizations of $\mathrm{Ni}-\mathrm{NiO}$ nanoparticles on PDDA-modified graphene for oxygen reduction reaction. Nanoscale Res. Lett. 2014, 9, 444. [CrossRef] [PubMed]

54. Cui, Y.; Wang, C.; Wu, S.; Liu, G.; Zhang, F.; Wang, T. Lotus-root-like NiO nanosheets and flower-like NiO microspheres: Synthesis and magnetic properties. Cryst. Eng. Comm. 2011, 13, 4930-4934. [CrossRef]

55. Mohan, S.; Srivastava, P.; Maheshwari, S.N.; Sundar, S.; Prakash, R. Nano-structured nickel oxide based DNA biosensor for detection of visceral leishmaniasis (Kala-azar). Analyst 2011, 136, 2845-2851. [CrossRef]

56. Zhang, W.; Yang, Z.; Liu, Y.; Tang, S.; Han, X.; Chen, M. Controlled synthesis of Mn3O4 nanocrystallites and MnOOH nanorods by a solvothermal method. J. Cryst. Growth 2004, 263, 394-399. [CrossRef]

57. Rahman, M.M.; Hussain, M.M.; Asiri, A.M.; Alamry, K.A.; Hasnat, M.A. An enzyme free detection of L-Glutamic acid using deposited CuO.GdO nanospikes on a flat glassy carbon electrode. Surfaces Interfaces 2020, 20, 100617. [CrossRef]

58. George, G.; Anandhan, S. Electrospun nickel oxide nanofiber webs for thermistor applications. Int. J. Plast. Technol. 2014, 18, 374-382. [CrossRef]

59. Ren, S.; Li, C.; Zhao, X.; Wu, Z.; Wang, S.; Sun, G.; Xin, Q.; Yang, X. Surface modification of sulfonated poly(ether ether ketone) membranes using nafion solution for direct methanol fuel cells. J. Membrane Sci. 2005, 247, 59-63. [CrossRef]

60. Wang, Z.; Liu, G.; Zhang, L.; Wang, H. Electrochemical detection of trace cadmium in soilusing a Nafion/stannum film-modified molecular wire carbon paste electrodes. Ionics 2013, 19, 1687-1693. [CrossRef]

61. Alam, M.M.; Asiri, A.M.; Uddin, M.T.; Islam, M.A.; Rahman, M.M. Wet-chemically prepared low-dimensional $\mathrm{ZnO} / \mathrm{Al} 2 \mathrm{O} 3 / \mathrm{Cr} 2 \mathrm{O} 3$ nanoparticles for xanthine sensor development using an electrochemical method. RSC Adv. 2018, 8, 12562-12572. [CrossRef]

62. Rahman, M.M.; Ahmed, J.; Asiri, A.M. Thiourea sensor development based on hydrothermally prepared CMO nanoparticles for environmental safety. Biosens. Bioelectron. 2018, 99, 586-592. [CrossRef] [PubMed]

63. Rahman, M.M.; Hussain, M.M.; Asiri, A.M. Bilirubin sensor based on CuO-CdO composites deposited in a nafion/glassy carbon electrode matrixes. Prog. Nat. Sci.Mater. Int. 2017, 27, 566-573. [CrossRef]

64. Rahman, M.M.; Hussain, M.M.; Asiri, A.M. Ultrasensitive and label-free detection of creatine based on CdO nanoparticles: A real sample approach. New J. Chem. 2017, 41, 6667-6677. [CrossRef]

65. Rahmana, M.M.; Ahmed, J.; Asiri, A.M. Development of Creatine sensor based on antimony-doped tin oxide (ATO) nanoparticles. Sens. Actuators B 2017, 242, 167-175. [CrossRef]

66. Alcantara, R.; Lavela, P.; Tirado, J.L. Structure and Electrochemical Properties of Boron-Doped $\mathrm{LiCoO}_{2}$. J. Solid State Chem. 1997, 134, 265-273. [CrossRef]

67. Zhao, L.; Su, G.; Liu, W.; Cao, L.n.; Wang, J.; Dong, Z.; Song, M. Optical and electrochemical properties of $\mathrm{Cu}$-doped $\mathrm{NiO}$ films prepared by electrochemical deposition. Appl. Surf. Sci. 2011, 257, 3974-3979. [CrossRef] 
68. Cheng, H.; Li, M.L.; Su, C.Y.; Li, N.; Liu, Z.Q. Cu-Co Bimetallic Oxide Quantum Dot Decorated Nitrogen-Doped Carbon Nanotubes: A High-Efficiency Bifunctional Oxygen Electrode for Zn-Air Batteries. Adv. Funct. Mater. 2017, 27, 1701833. [CrossRef]

69. Malkhandi, S.; Yang, B.; Manohar, A.K.; Manivannan, A.; Prakash, G.K.S.; Narayanan, S.R. Electrocatalytic Properties of Nanocrystalline Calcium-Doped Lanthanum Cobalt Oxide for Bifunctional Oxygen Electrodes. J. Phys. Chem. Lett. 2012, 3, 967-972. [CrossRef]

70. Marshall, A.T.; Haverkamp, R.G. Electrocatalytic activity of $\mathrm{IrO} 2-\mathrm{RuO} 2$ supported on Sb-doped $\mathrm{SnO} 2$ nanoparticles. Electrochim. Acta 2010, 55, 1978-1984. [CrossRef]

71. Alam, M.M.; Asiri, A.M.; Uddin, M.T.; Islam, M.A.; Awual, M.R.; Rahman, M.M. Detection of uric acid based on doped $\mathrm{ZnO} / \mathrm{Ag}_{2} \mathrm{O} / \mathrm{Co}_{3} \mathrm{O}_{4}$ nanoparticles fabricated glassy carbon electrode. New J. Chem. 2019, 43, 8651-8659. [CrossRef]

72. Hussain, M.M.; Rahman, M.M.; Asiri, A.M.; Awual, M.R. Non-enzymatic simultaneous detection of L-glutamic acid and uric acid using mesoporous Co3O4 nanosheets. RSC Adv. 2016, 6, 80511-80521. [CrossRef]

73. Abu-Zied, B.; Alam, M.M.; Asiri, A.M.; Ahmed, J.; Rahman, M.M. Efficient hydroquinone sensor development based on $\mathrm{Co}_{3} \mathrm{O}_{4}$ nanoparticle. Microchemical J. 2020, 157, 104972. [CrossRef]

74. Alam, M.M.; Asiri, A.M.; Uddin, M.T.; Islam, M.A.; Awual, M.R.; Rahman, M.M. One-step wet-chemical synthesis of ternary $\mathrm{ZnO} / \mathrm{CuO} / \mathrm{Co}_{3} \mathrm{O}_{4}$ nanoparticles for sensitive and selective melamine sensor development. New J. Chem. 2019, 43, 4849-4858. [CrossRef]

75. Rahman, M.M.; Alam, M.M.; Asiri, A.M. Development of an efficient phenolic sensor based on facile Ag2O/Sb2O3 nanoparticles for environmental remediation. Nanoscale Adv. 2019, 1, 696-705. [CrossRef]

76. Alam, M.M.; Asiri, A.M.; Uddin, M.T.; Islam, M.A.; Rahman, M.M. In-situ glycine sensor development based $\mathrm{ZnO} / \mathrm{Al} 2 \mathrm{O} / \mathrm{Cr} 2 \mathrm{O} 3$ nanoparticles. ChemistrySelect 2018, 3, 11460-11468. [CrossRef]

77. Akhter, H.; Murshed, J.; Rashed, M.A.; Oshima, Y.; Nagao, Y.; Rahman, M.M.; Asiri, A.M.; Hasnat, M.A.; Uddin, M.N.; Siddiquey, I.A. Fabrication of hydrazine sensor based on silica-coated Fe2O3 magnetic nanoparticles prepared by a rapid microwave irradiation method. J. Alloys. Compounds 2017, 698, 921-929. [CrossRef]

78. Awual, M.R.; Hasan, M.M.; Islam, A.; Rahman, M.M.; Asiri, A.M.; Khaleque, M.A.; Sheikh, M.C. Introducing an an amine functionalized novel conjugate material for toxic nitrite detection and adsorption from wastewater. J. Clean. Prod. 2019, 228, 778-785. [CrossRef]

79. Rahman, M.M.; Karim, M.R.; Alam, M.M.; Zaman, M.B.; Alharthi, N.; Alharbi, H.; Asiri, A.M. Facile and efficient 3-chlorophenol sensor development based on photolumenescent core-shell CdSe/ZnS quantum dots. Sci. Rep. 2020, 10, 557. [CrossRef]

Publisher's Note: MDPI stays neutral with regard to jurisdictional claims in published maps and institutional affiliations.

(C) 2020 by the authors. Licensee MDPI, Basel, Switzerland. This article is an open access article distributed under the terms and conditions of the Creative Commons Attribution (CC BY) license (http://creativecommons.org/licenses/by/4.0/). 